\title{
Recenzja
}

\section{Systemy polityczne wybranych państw basenu Morza Śródziemnego, pod red. M. Myśliwiec i K. Krysieniel, Wydawnictwo Wyższej Szkoły Bankowej w Poznaniu, Poznań-Chorzów 2011 , ss. 230}

Recenzowana książka jest pierwszym w polskiej literaturze ustrojowoporównawczej dziełem koncentrującym się na problematyce systemów politycznych państw basenu Morza Śródziemnego. Już sam ten precedensowy jej charakter musi przyciągnąć uwagę czytelnika zainteresowanego zagadnieniami ustrojowymi państw współczesnych. Pomysł przeprowadzenia analizy naukowej systemów politycznych państw śródziemnomorskich zrodził się na Wydziale Zamiejscowym w Chorzowie Wyższej Szkoły Bankowej w Poznaniu. Redakcji naukowej opracowania zawierającego taką analizę podjęli się powiązani z tym Wydziałem: Małgorzata Myśliwiec i Krzysztof Krysieniel. Spośród 21 państw położonych nad Morzem Śródziemnym (nie licząc Gibraltaru i Strefy Gazy) w pracy zostało zaprezentowanych 6, w przyjętej kolejności ich opisu: Francja (Anna Kuczyńska), Włochy (Małgorzata Lorencka), Hiszpania (Małgorzata Myśliwiec), Maroko (Małgorzata Myśliwiec), Chorwacja (Krzysztof Krysieniel) i Grecja (Małgorzata Lorencka). Opisy te poprzedza krótki, pięciostronicowy tekst, w zamiarze mający służyć jako słowo wstępne, przygotowany przez Piotra Świercza o znaczeniu basenu Morza Śródziemnego w świecie antycznym, nota bene w mojej ocenie interesujący, ale pozostający raczej w luźnym związku z problematyką współczesnych systemów politycznych państw tego regionu, a tym samym niewiele wnoszący do zrozumienia ich istoty i oceny.

W przypadku każdego opracowania, którego przedmiotem są systemy ustrojowe określonej grupy państw, siłą rzeczy nasuwa się pytanie o kryterium jej wyodrębnienia. W recenzowanym dziele naturalnym takim kryterium jest położenie geograficzne. Większość państw z tej grupy łączy oprócz tego uczestnictwo w powołanym w 2008 r. projekcie zw. „procesem barcelońskim”, którego celem jest zaciśnięcie więzi politycznych, ekonomicznych, kulturowych i w dziedzinie bezpieczeństwa międzynarodowego. Podjęcie się 
realizacji tego projektu stworzyło również dogodniejsze warunki do oddziaływań międzypaństwowych w zakresie kształtowania krajowych systemów politycznych. Ma to istotne znaczenie, ponieważ podniesiony przez Redaktorów książki, Krzysztofa Krysieniela i Małgorzatę Myśliwiec, jak też Autora wprowadzenia - Piotra Świercza, problem „wzajemnego wpływu rozwiązań ustrojowych, przyjmowanych na gruncie poszczególnych państw regionu" (s. 8), ich „pokrewieństwa lub podobieństwa form polityczno-prawnych" (s. 12-13), należy potraktować raczej jako próbę optymistycznego spojrzenia w przyszłość aniżeli podsumowanie dotychczasowego stanu rzeczy. Jak dotąd, uwidaczniały się przede wszystkim znaczne rozbieżności ustrojowe, nadzwyczaj wyraźne między demokratycznymi państwami europejskimi a położonymi w Afryce Północnej autorytarnymi państwami arabskimi. Jeżeli można było mówić o wzajemnym oddziaływaniu państw w interesującej nas sferze, to zachodziły one do niedawna głównie w ramach wymienionych grup państw. Szersze pole do demokratyzacji ustrojów państw arabskich, a tym samym wdrażania elementów europejskich wzorców ustrojowych, otworzyło się dopiero w następstwie burzliwych przewrotów politycznych zapoczątkowanych w Tunezji w styczniu 2011 r. Opisany w książce przypadek Maroka „pokojowych” reform politycznych, które zaowocowały zatwierdzeniem w drodze referendum w dniu 1 lipca 2011 r. nowej konstytucji jest jednym z sygnałów, że nie będzie o to łatwo; jak wskazuje trafnie Małgorzata Myśliwiec, system polityczny Maroka „choć wzorowany na niektórych rozwiązaniach europejskich, znacznie odbiega od koncepcji znanych nam państw demokratycznych", będąc w swej istocie systemem autorytarnym (s. 175). Wypada też odnotować, iż w ramach wskazanych wyżej obu grup państw śródziemnomorskich systemy polityczne także są dalekie od jednorodności, czego wyrazem są występujące w nich różne modele systemów rządów. Dowodnie wykazują to chociażby systemy rządów państw europejskich omówionych w recenzowanym dziele, nie mówiąc już o zróżnicowanych formach ustrojowych sprawowania władzy w państwach arabskich.

W świetle powyższych uwag brak w opracowaniu analiz wzajemnych oddziaływań ustrojowych, których można byłoby przecież spodziewać się po wspomnianych wyżej, nieco "pochopnych” anonsach we wstępnych jego partiach, i koncentracja na „wyizolowanej”, wolnej od opisu wpływów zewnętrznych, prezentacji systemów politycznych wybranych państw basenu 
Morza Śródziemnego stają się w jakimś stopniu zrozumiałe i tym samym nie wywołują głębszego uczucia niedosytu.

Inna rzecz, że wybór państw mógł być nieco inny. W książce zostały przedstawione, przypomnijmy, systemy polityczne: Francji, Włoch, Hiszpanii, Maroka, Chorwacji i Grecji. W oczy rzuca się „niedoreprezentowanie” państw z południowych i wschodnich obrzeży tego basenu, czego tylko częściowym wytłumaczeniem może być zachodzący w niektórych z nich proces przemian ustrojowych. Zwraca też uwagę pominięcie bardzo ważnych i ustrojowo interesujących państw, jakimi są Turcja i Izrael. Rekompensatą jest merytorycznie wysoki poziom prezentacji systemów politycznych państw, które są przedmiotem analiz.

Stwierdzić przede wszystkim należy, że poszczególne opracowania odznaczają się trafną i klarowną identyfikacją poruszanych w nich zagadnień, co stanowi konsekwencję właściwego redakcyjnego ich zunifikowania i uporządkowania. Na strukturę tych opracowań składają się (z pewnymi, raczej niewielkimi, odstępstwami, widocznymi zwłaszcza w tekście o Chorwacji) kolejno omawiane następujące problemy: 1) zarys historii konstytucjonalizmu danego państwa, 2) uchwalenie obowiązującej konstytucji, tryb jej zmiany i ogólna charakterystyka, 3) forma organizacji terytorialnej państwa, 4) system wolności i praw obywatelskich, 5) system partyjny a system wyborczy, 5) władza ustawodawcza, 6) władza wykonawcza, 7) władza sądownicza, 8) system ochrony konstytucyjnych praw jednostki. Taka ujednolicona konstrukcja nie tylko czyni całe dzieło bardziej komunikatywnym, ale również umożliwiła omówienie wszystkich węzłowych zagadnień z zakresu przedstawianych systemów politycznych. Być może warto byłoby jednak wyodrębnić dodatkowo - znajdującą się zdecydowanie poza marginesem przeprowadzanych w książce rozważań - problematykę pozawyborczych form partycypacji społecznej w sprawowaniu władzy publicznej (ew. podmiotowości politycznej jednostki), która jest bardzo istotna z punktu widzenia ogólnej charakterystyki i oceny poszczególnych systemów politycznych. W ewentualnym ponownym wydaniu tej książki (poszerzonym!) sugerowałbym ponadto uzupełnienie dwóch opracowań o wnioski, a tych, które je zawierają - pewne, choćby niewielkie, ich wzbogacenie, jak też dodanie do aneksu tabel prezentujących rezultaty wyborów parlamentarnych, ukształtowane w ich wyniku struktury polityczne składów osobowych par- 
lamentów oraz zawierających informacje o rządach każdego z omawianych państw.

Obszerność poszczególnych opracowań jest zróżnicowana, co jest głównie spowodowane niejednakową głębią analiz $\mathrm{w}$ nich przeprowadzonych. Mimo to, zarysowany obraz systemu politycznego danego państwa, wprawdzie mniej lub bardziej syntetyczny, jest w każdym wypadku przejrzysty i kompleksowo obejmujący wszystkie istotne jego aspekty, kompetentny i sporządzony z niewątpliwym znawstwem poruszanej problematyki. Na tle pozostałych, bezsprzecznie wartościowych tekstów, wyróżnia się studium o Francji, nie tylko ze względu na największą liczbę stron, lecz również oryginalność, kompletność ujęcia systemu politycznego tego państwa i bogactwo wykorzystanej literatury. Pozostałe teksty tylko w bardzo nieznacznym stopniu odbiegają poziomem od tego studium; wysiłek włożony w ich przygotowanie jest godny uznania. Bez wątpienia wszyscy Autorzy stanęli na wysokości zadania, tworząc wspólnie dzieło o dużych walorach poznawczych.

Generalnie wysokiej mojej oceny poziomu merytorycznego wszystkich opracowań w niczym nie umniejszają dwie następujące kwestie. Pierwsza z nich dotyczy - moim zdaniem - nadmiernie sprawozdawczego, wyłącznie informacyjnego - pozbawionego elementu refleksji - charakteru niektórych fragmentów książki. Uzupełniające komentarze dowartościowałyby te fragmenty jeszcze bardziej i byłyby pomocne w pełniejszym zrozumieniu przez czytelnika omawianych w nich zagadnień. Druga kwestia jest natury terminologicznej: zachęcałbym do pewnej wstrzemięźliwości w operowaniu anachronicznymi pojęciami: „izba niższa” i „izba wyższa”, współcześnie zwykle nie korelującymi z rzeczywistym usytuowaniem tych zgromadzeń w strukturze parlamentu, a tym samym mylącymi.

Konkludując: omawiana książka jest pozycją, którą śmiało można polecić wszystkim zainteresowanym systemami politycznymi państw obcych. Można ją uznać za cenne dopełnienie stale powiększającej się liczby wydawnictw poświęconym tym systemom, choćby z powodzeniem firmowanych przez Wydawnictwo Sejmowe.

Grzegorz Kryszeń (Uniwersytet w Białymstoku) 